\title{
Fictie als bron van kennis
}

\author{
Frans Meulenberg
}

Ieder mens moet het maar zelf zien uit te vinden, hoe hij in het leven wil staan. Onze dagelijkse ervaringen staan daarbij voorop en zijn een uitstekend hulpmiddel. Bijvoorbeeld: intieme relaties geven vorm en betekenis aan ons leven. Relaties - met de subkenmerken liefde, vriendschap, altruïsme, betrokkenheid enzovoorts - zijn bouwstenen voor wie en wat wij zijn en willen zijn. De geboorte van een kind, de ziekte van een familielid, een gezamenlijke geschiedenis als goede vrienden: dit alles verschaft ons nieuwe inzichten, een betere en meer adequate visie op het leven en de eigen rol daarin.

'Echte' ervaring is weliswaar een belangrijke bron voor de morele attitudevorming, maar dat kan nimmer de enige bron zijn. Reflectie alleen is onvoldoende voor volwassen morele oordeelsvorming, simpelweg omdat wij te weinig meemaken. Hongersnood, moord, kindermishandeling, dierproeven, oorlog of een dictatuur: wij hebben er een (moreel) oordeel over, zonder dat wij dit noodzakelijkerwijs aan den lijve hebben ondervonden. Er is dus meer voeding nodig. In welke zin kan fictie literatuur, toneel, film - daarbij helpen? Fictie schenkt ons gedetailleerde beelden, indringende beschrijvingen van levens en karakters, plus de complexiteit hiervan. Voedingsstof voor morele overwegingen dus. Hoe? Door te wijzen op de subtiliteiten van zaken die onze aandacht verdienen, scherpt fictie ons vermogen aan om morele nuances te onderscheiden. Behalve het vermogen tot ontroering heeft fictie dus morele kracht. Fictie is zelfs een bron van kennis, maar dat wordt al te vaak onderschat.

Frans Meulenberg $(\bowtie)$

Frans Meulenberg, publicist en in deeltijd werkzaam als onderzoeker Ethiek en fictie bij de afdeling Medische ethiek en filosofie van de geneeskunde, Erasmus MC, Rotterdam, f. meulenberg@erasmusmc.nl.

\section{Hersenbeuker}

Neem genetica. Het publiek wordt via de media overspoeld met nieuws over genetica, maar blijft desondanks volstrekt onkundig van of vol misvattingen over de stand van zaken in de wetenschap hierover. Dat blijkt uit het rapport Publiekskennis genetica van de Gezondheidsraad. Hoe komt dat? Omdat de publieke opinie over vooral technologische vooruitgang sterk door fictie wordt beïnvloedt. Zo hangt boven kloneren nog steeds de doem van de roman en film The Boys from Brazil. Fictie lijkt dus een krachtiger medium dan wetenschappelijke informatie. Het 'bewijs' voor deze stelling ontleen ik aan de roman Witte tanden van Zadie Smith.

Wetenschapper Marcus Chalfen schreef in samenwerking met een romancier een populair wetenschappelijk werk over DNA: Tijdbommen en biologische klokken: een avontuurlijke reis in onze genetische toekomst. Zittend in de vertrekhal van Heathrow, spreekt een meisje hem aan. Op haar schoot ligt het boek van Marcus. Of zij het een goed boek vindt, vraagt hij. "O, het gaat wel, denk ik. Een beetje raar wel. Een beetje een hersenbeuker." Het antwoord bevredigt Marcus nauwelijks. Het boek was, naar een idee van de uitgever, geschreven op twee niveaus, hoog en laag. Marcus zorgde voor de wetenschappelijke passages over genetica, terwijl de romanschrijver een soort verkenning schreef, vanuit een fictief en futuristisch uitgangspunt, in de trant van wat-als-ditzou-leidentot- dit, enzovoorts. Marcus had aan het plan toegegeven. Er ontwikkelt zich de volgende dialoog.

"Niet raar, denk ik, éng eerder."

"Eng, hoe?"

"Nou, het is toch eng, al dat genetische gemanipuleer."

"Is dat zo?" 
Dan volgt een lange monoloog waarin het meisje haar standpunt toelicht: " $Z \mathrm{Zij}$ hebben het over stappen vooruit en achteruit op medisch gebied, blablabla, maar denk je niet, en daar komt het uiteindelijk op neer, dat als iemand weet hoe je 'ongewenste' eigenschappen bij mensen kunt wegnemen dat een of andere regering daar geen gebruik van zal maken? Ik bedoel, wat is ongewenst? Er zit een beetje fascistisch kantje aan dat hele gedoe.... Het is wel een goed boek, neem ik aan, maar bij sommige dingen denk je: waar gaan wij eigenlijk heen? Miljoenen blondjes met blauwe ogen? Postorderbaby's? Ik bedoel, als je Indiaas bent, zoals ik, heb je wel iets om je zorgen over te maken, ja? En dan planten ze kankercellen in arme beesten, maar wie ben jij om te rotzooien met de eigenschappen van een muis? Een dier scheppen om het te laten sterven - dat is voor God spelen! (...) Het is gewoon onnatôôrlijk!"

Het meisje hanteert alle klassieke argumenten - het hellende vlak, het voor God spelen, onnatuurlijkheid, eugenetica - om haar standpunt toe te lichten. Marcus is verbijsterd. Nergens schreef hij ook maar iets over menselijke eugenese. Toch slaagt het meisje erin het boek bijna uitsluitend vanuit dat perspectief te lezen. Marcus mist een cruciaal punt: alle meningen en misvattingen die het meisje debiteert over gentechnologie zijn niet veroorzaakt door Marcus' bijdrage, maar juist door de passages van de romanschrijver!

\section{Docententroost}

Onderwijs via fictie biedt prima mogelijkheden om ethische dilemma's en de onderliggende argumenten te tonen, te analyseren en te gebruiken voor mogelijke heroverweging van eigen standpunten. Er is nog een aantrekkelijk extra winstpuntje voor de docent. Liggend op het strand met een medische thriller - wat regelmatig gebeurt - koester ik de gedachte: "ik ben aan het werk". En 's avonds, zongebruind kijkend op televisie naar films als X-Men of Star Trek, weten mijn huisgenoten heel goed dat zij mij niet moeten storen: "ssttt, hij is aan het werk." 